\title{
EFFECT OF DIFFERENT CARBON DIOXIDE GAS CONCENTRATIONS USED DURING THE INSEMINATION OF HONEY BEE QUEENS ON STARTING OVIPOSITION
}

\author{
Malgorzata Bieńkowska, Beata Panasiuk, \\ Pawel Wegrzynowicz, Dariusz Gerula
}

\begin{abstract}
Research Institute of Horticulture, Apiculture Division, Kazimierska 2, 24-100 Puławy, Poland e-mail: malgorzata.bienkowska@man.pulawy.pl
\end{abstract}

Received 20 January 2012; accepted 31 May 2012

$\mathrm{S} \mathrm{u} \mathrm{m} \mathrm{m} \mathrm{a} \mathrm{r} \mathrm{y}$

The experiment was conducted in 2004, 2005 and 2007 at the Research Institute of Pomology and Floriculture, Apiculture Division in Puławy, Poland. Carniolan sister queens at the age of 7 days were inseminated with an $8 \mu$ dose of semen. Queens were anesthetized once during the insemination with different concentrations of carbon dioxide and air gas mixtures. It took queens a shorter time to be narcotized when $\mathrm{CO}_{2}$ was given at higher concentrations. The timing was from $6.1 \mathrm{~s}$ when $100 \% \mathrm{CO}_{2}$ was used to $95.5 \mathrm{~s}$ when $50 \% \mathrm{CO}_{2}$ was used. Semen injection took longer in queens anaesthetized with $\mathrm{CO}_{2}$ at the lower $50 \%$ and $75 \%$ concentrations. The queens remained anesthetized significantly longer when higher $\mathrm{CO}_{2}$ concentrations were used.

Among 276 instrumentally inseminated queens, 88\% started laying eggs before the end of the experiment and $12 \%$ did not start laying eggs, or died before the end of the experiment. The highest percentage of queens that did not start laying eggs or died was noted in the group anaesthetized with $75 \%$ and $80 \%$ of $\mathrm{CO}_{2}(16.4 \%$ and $14.5 \%)$. In the other groups, the percentage of queens who did not start laying eggs or died ranged from $7.4 \%$ to $14.5 \%$. Different $\mathrm{CO}_{2}$ gas concentrations used for immobilization of bee queens during instrumental insemination significantly influenced oviposition of queens. Instrumentally inseminated bee queens began laying eggs 4 to 55 days after the insemination. The significantly shortest time from insemination to oviposition was noted in queens that were narcotized with 50,100 and $90 \%$ of $\mathrm{CO}_{2}(17.4,17.6$ and 19.9 days respectively). The longest time was noted in queens treated with $75-80 \%$ of $\mathrm{CO}_{2}$ (after 22 days).

Keywords: Apis mellifera, anesthesia, carbon dioxide, nitrogen, oxygen, instrumental insemination.

\section{INTRODUCTION}

In natural conditions, after bee queens copulate with drones, the unknown stimuli triggers the activation of the queen's ovaries and of egg laying (Alber et al., 1955; Koeniger, 1976, 1981; Koeniger et al., 1979). The carbon dioxide used for queen immobilization during instrumental insemination causes egg laying to start earlier in inseminated queens. According to Mackensen (1947), double $\mathrm{CO}_{2}$ treatments lasting 10 minutes each, significantly shortened the period from the insemination to oviposition. Fischer (1990) stated that bee queens which were anaesthetized on the day before insemination and then during the treatment were characterized as having better sperm migration into the spermatheca. Previous studies have also shown that anaesthesia of queens the day before instrumental insemination inhibits them from performing post-insemination mating flights (Woyke et al., 1995, 2001). But it was shown that the effect of carbon dioxide is not neutral for both the queens and the workers. The effect of carbon dioxide changes both 
queen and worker behavior (Austin, 1955; Skowronek and Jaycox, 1974; Skowronek, 1976, 1982; Ebadi et al.,1980, Wilde and Sobiechowski, 2002). Czekońska (2009) found that worker bees treated with low concentrations of $\mathrm{CO}_{2}$ lived significantly longer than those treated with a gas concentration that was higher than $80 \%$. Negative consequences of narcosis are greater, the longer the duration of anesthesia and the older the treated individual. Attempts to shorten the anaesthesia duration and dividing it into two gas applications for a total of six minutes, gave the same effect as a double 10-minute anesthesia treatment (Konopacka, 1989). Ebadi and Gary (1980) used a mixture of $50-90 \% \mathrm{CO}_{2}$ gas and air gases. The queens immobilized with this mixture began laying eggs faster than the queen anesthetized with pure $\mathrm{CO}_{2}$. Queens treated twice for 10 minutes with a $75 \% \mathrm{CO}_{2}$ narcosis, began laying eggs after an average of 3.7 days. This was almost as soon as the naturally mated ones. It was also found that instrumentally inseminated queens begin oviposition 8-12 days after insemination without a second $\mathrm{CO}_{2}$ treatment (Woyke, 1962, 1966). According to Harbo (1986 $\mathrm{a}, \mathrm{b})$, virgin queens, which were kept in the queen banks for about 2 months before insemination, started laying eggs without anesthesia.

Since there is a large-scale production of honey bee queens (about 30 thousand per year in Poland), it is important to determine the factors affecting the quality of inseminated queens. Many problems have already been explained in this field but the reason for the significant delay in oviposition starting in instrumentally inseminated queens has not been explained (Bieńkowska and Panasiuk 2006; Bieńkowska et al., 2008, 2011; Gerula and Bieńkowska, 2008; Gontarz et al., 2005; Konopacka, 1989; Laidlaw, 1954, 1981; Mackensen,1964; Woyke, 1960, 1979, 1983; Woyke and Jasiński, 1973, 1976, 1978, 1980, 1982 a,b, 1990).

The aim of this research was to determine the impact on the start of oviposition of the various concentrations of $\mathrm{CO}_{2}$ used for bee queen immobilization during instrumental insemination.

\section{MATERIAL AND METHODS}

The study was conducted in the years 2004, 2005 and 2007 at the Apiculture Division of the Research Institute of Horticulture (previous Research Institute of Pomology and Floriculture) in Puławy, Poland. Carniolan sister queens were reared from one day old larvae. Sealed queen cells, 5-days from larvae grafting, were transferred into incubators. The temperature of the incubators was $35^{\circ} \mathrm{C}$. Emerged queens were introduced into mating hives. A total of 276 queens were inseminated with a dose of $8 \mu \mathrm{l}$ of semen at the age of 7 days. Queens were anesthetized only once during the insemination. The following mixtures of carbon dioxide and air gases were used for anesthetizing the queens:

$$
\begin{aligned}
& 100 \% \mathrm{CO}_{2}, \\
& 90 \% \mathrm{CO}_{2}-2.1 \% \mathrm{O}_{2}-7.9 \% \mathrm{~N}_{2}, \\
& 80 \% \mathrm{CO}_{2}-15.82 \% \mathrm{O}_{2}-4.18 \% \mathrm{~N}_{2}, \\
& 75 \% \mathrm{CO}_{2}-5.25 \% \mathrm{O}_{2}-19.75 \% \mathrm{~N}_{2}, \\
& 50 \% \mathrm{CO}_{2}-10.5 \% \mathrm{O}_{2}-39.5 \% \mathrm{~N}_{2} .
\end{aligned}
$$

Factors listed below were estimated during the insemination process:

1. the time it took to immobilize queens when treated with carbon dioxide at different concentrations (100\%, 90\%, $85 \%, 75 \%$ and $50 \%$ ) - from the beginning of exposure to $\mathrm{CO}_{2}$, to full narcosis,

2. the time needed for inseminating the queens - opening of the sting chamber and introducing the semen into the queen's reproductive tract,

3. the time it took for the queens to come to. This includes the time from the end of the $\mathrm{CO}_{2}$ application till when the queens started moving and walking,

4. the duration of the whole insemination process.

For the statistical data analysis, the nonparametric Kruskal-Wallis test was used. Nucleus colonies were inspected for initiation of oviposition once a week, up to 60 days after insemination. An evaluation of the percentage of egg laying and non- 
egg laying queens was done at this time. The differences between averages of studied parameters and interaction between various $\mathrm{CO}_{2}$ concentrations and days from insemination to oviposition were analyzed using the $\chi^{2}$ test and the confidence coefficient.

\section{RESULTS}

In all of the years of this research study, the higher the concentration of carbon dioxide gas used for anesthesia the shorter the time it took to immobilize the queens (Tab. 1). Queen immobilization time ranged from $6.1 \mathrm{~s}$ after application of $100 \% \mathrm{CO}_{2}$ in 2005 , to $95.5 \mathrm{~s}$ when $50 \% \mathrm{CO}_{2}$ was applied in 2004. The averages obtained during the 3 -years of research showed that the moment of immobilization after the application of $\mathrm{CO}_{2}$ at different concentrations, was significantly different (Kruskal-Wallis test $\mathrm{H}(4, \mathrm{~N}=276)=232.73 ; \mathrm{p}=0.000)$, but the longest was in the first year of the research (Kruskal-Wallis test $\mathrm{H}$ $(4, \mathrm{~N}=276)=9.04 ; \mathrm{p}=0.0109)$. The queens treated with $100 \% \mathrm{CO}_{2}$ were immobilized the fastest (after about $7.3 \mathrm{~s}$ on average). The queens that were treated with $\mathrm{CO}_{2}$ at lower concentrations took a significantly slower time to become immobilized (after $16.7 \mathrm{~s}$ to $81.5 \mathrm{~s}$ on average). There were no differences in the time it took for queens to become immobilized for queens treated with $\mathrm{CO}_{2}$ at 75 and $80 \%$ concentrations, in all the years of the research study.
In our study, the shortest time needed to introduce the semen into the oviducts of queens was for those queens treated with $80 \%$ and $90 \% \mathrm{CO}_{2}$ concentrations (average 12.5 and $11.4 \mathrm{~s}$ ). This tendency repeated each year, but the differences were not always significant.

The whole insemination process was the longest in the first year of the study (Kruskal-Wallis test $\mathrm{H}(4, \mathrm{~N}=276)=$ 35.47; $\mathrm{p}=0.000)$. As expected, in all of the study years, the queens treated with $\mathrm{CO}_{2}$ at higher concentrations were waking up significantly more slowly (average from $18.3 \mathrm{~s}$ to $155.7 \mathrm{~s}$; Kruskal-Wallis test $\mathrm{H}$ $(4, \mathrm{~N}=276)=207.5 ; \mathrm{p}=0.000)$. The queens woke up the most slowly in the first year of the study (Kruskal-Wallis test $\mathrm{H}$ (4, $\mathrm{N}=100)=75.6 ; \mathrm{p}=0.000)$.

The average time of the whole insemination process, from the start of the $\mathrm{CO}_{2}$ application till when the queens fully awaken, differed significantly between the groups of queens anesthetized with $\mathrm{CO}_{2}$ at various concentrations (Kruskal-Wallis test $\mathrm{H} \quad(4, \mathrm{~N}=276)=135.9, \mathrm{p}=0.000)$. In each year of the study, the time of the insemination process was significantly shortest after applying 75\% $\mathrm{CO}_{2}$ (average $82.6 \mathrm{~s}$; from $66.5 \mathrm{~s}$ in 2005 to $111.1 \mathrm{~s}$ in 2004). The queens treated with pure $\mathrm{CO}_{2}$ remained immobilized the longest (average $132 \mathrm{~s}$; from 162.7 in 2005 to $208.0 \mathrm{~s}$ in 2004) (Tab. 1).

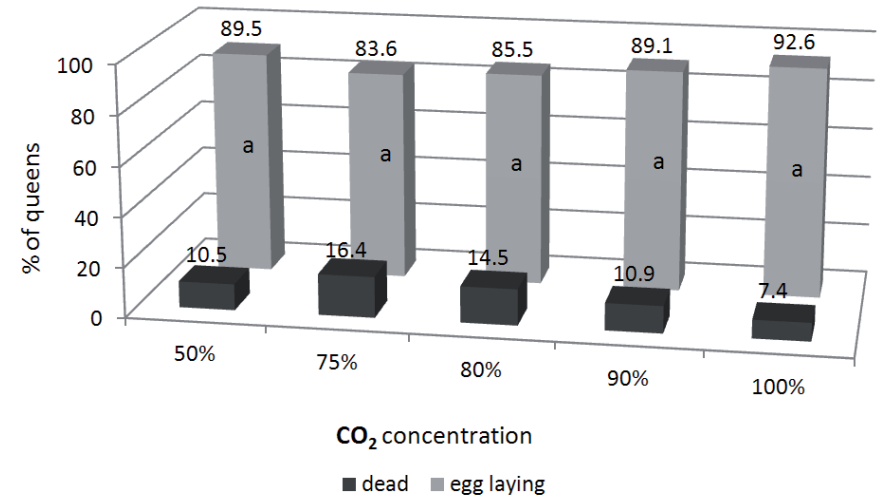

Fig. 1. Percentage of egg laying and dead queens. a- no statistical differences $\chi^{2}=4.22, \mathrm{df}=4, \mathrm{p}=0.377$. 


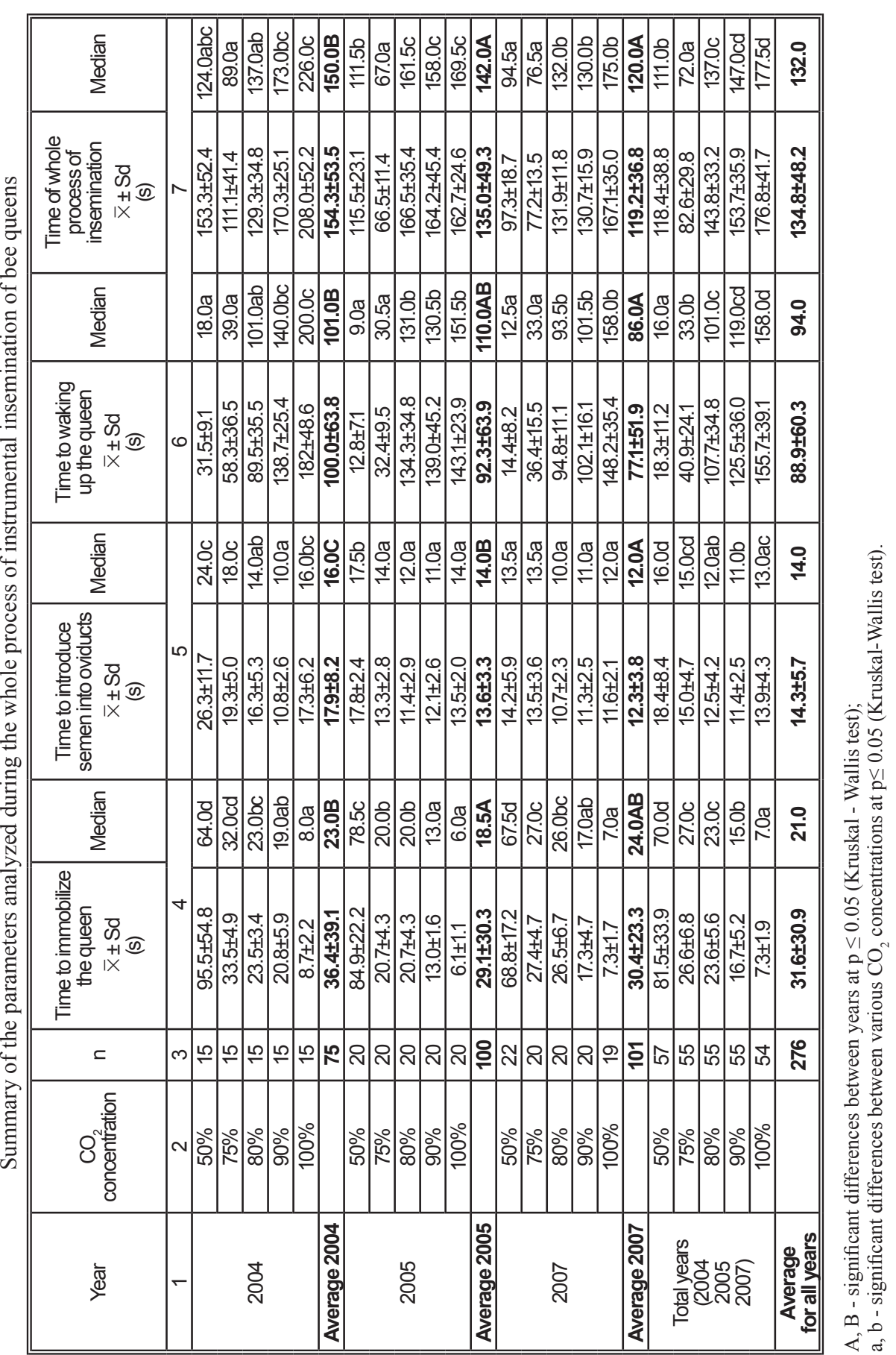


The number of egg laying, non-egg laying, and dead queens

\begin{tabular}{|c|c|c|c|c|c|}
\hline \multirow[b]{2}{*}{ Year } & \multirow[b]{2}{*}{$\begin{array}{c}\text { No of } \\
\text { inseminated } \\
\text { queens }\end{array}$} & \multicolumn{4}{|c|}{ No of queens } \\
\hline & & $\begin{array}{l}\text { Egg laying } \\
\text { queens }\end{array}$ & $\%$ & $\begin{array}{l}\text { Dead and } \\
\text { non-egg } \\
\text { laying queens }\end{array}$ & $\%$ \\
\hline 2004 & 75 & 68 & $90.7 a$ & 7 & $10.3 a$ \\
\hline 2005 & 100 & 90 & $88.9 a$ & 10 & $11.1 \mathrm{a}$ \\
\hline 2007 & 101 & 85 & $84.2 a$ & 16 & $15.8 \mathrm{a}$ \\
\hline Total & 276 & 243 & 88.1 & 33 & 11.9 \\
\hline
\end{tabular}

$\mathrm{a}$ - no differences at $\mathrm{p} \leq 0.05$ (Difference test between two proportions);

$\chi^{2}=0.02, \mathrm{p}=0.883$ between 2004 and 2005;

$\chi^{2}=1.6, \mathrm{p}=0.205$ between 2004 and 2007;

$\chi^{2}=1.52, \mathrm{df}=4, \mathrm{p}=0.217$ between 2005 and 2007 .

Table 3 .

Interactions between various $\mathrm{CO}_{2}$ gas concentrations used during insemination and initiation of oviposition by instrumentally inseminated queens

\begin{tabular}{||c|c|c|c|c||}
\hline \hline Year & $X^{2}$ & df & $P$ & $\begin{array}{c}\text { Confindency } \\
\text { coefficient }\end{array}$ \\
\hline 2004 & 141.5 & 72 & 0.0000 & 0.808 \\
\hline 2005 & 192.2 & 128 & 0.0009 & 0.811 \\
\hline 2007 & 75.4 & 68 & 0.1978 & 0.653 \\
\hline Total & 215.7 & 152 & 0.0000 & 0.662 \\
\hline
\end{tabular}

Table 4 .

Comparison of oviposition period in queens anesthetized with various $\mathrm{CO}_{2}$ gas concentrations

\begin{tabular}{||c|c|c|c|c||}
\hline \hline \multirow{2}{*}{$\begin{array}{c}\mathrm{CO}_{2} \text { gas } \\
\text { concentrations }\end{array}$} & \multirow{2}{*}{$\begin{array}{c}\text { No of } \\
\text { queens }\end{array}$} & \multicolumn{3}{|c||}{ Days to oviposition } \\
\cline { 3 - 5 } & 51 & $4-(37)$ & $17.4 \pm 8.8$ & $18 \mathrm{a}$ \\
\hline $50 \%$ & 46 & $9-49$ & $23.1 \pm 11.8$ & $22 \mathrm{ab}$ \\
\hline $75 \%$ & 47 & $6-55$ & $24.3 \pm 10.9$ & $22 \mathrm{~b}$ \\
\hline $80 \%$ & 49 & $6-54$ & $19.9 \pm 11.5$ & $20 \mathrm{ab}$ \\
\hline $90 \%$ & 50 & $8-43$ & $17.6 \pm 8.9$ & $15 \mathrm{a}$ \\
\hline $100 \%$ & 243 & $4-55$ & $20.4 \pm 10.7$ & 20 \\
\hline Total & & &
\end{tabular}

$\mathrm{a}, \mathrm{b}$ - different letters indicate significant differences at $\mathrm{p} \leq 0.05$;

Kruskal-Wallis test: $\mathrm{H}(4, \mathrm{~N}=243)=18.1783, \mathrm{p}=0.0011$.

Among 276 instrumentally inseminated queens, $243(88.1 \%)$ individuals started laying eggs but no significant differences were found between the different years of the study (Tab. 2). Oviposition was started by $89.5 \%\left(50 \% \mathrm{CO}_{2}\right), 83.6 \%\left(75 \% \mathrm{CO}_{2}\right)$, $85.5 \%\left(80 \% \mathrm{CO}_{2}\right), 89.1 \%\left(90 \% \mathrm{CO}_{2}\right)$ and $92.6 \%\left(100 \% \mathrm{CO}_{2}\right)$ of the queens. The groups did not differ significantly in the percentages of queens starting oviposition $\left(\chi^{2}=4.22, \mathrm{df}=4, \mathrm{p}=0.377\right)$, (Fig.1).
A high dependency between the concentration of $\mathrm{CO}_{2}$ used during instrumental insemination of bee queens and oviposition was noted (Tab. 3). A high dependency was not noted only in the last year of the research study. Instrumentally inseminated bee queens began laying eggs 4 to 55 days after insemination. The significantly shortest time from insemination to oviposition was found to be in queens that were narcotized with 50 and $100 \% \mathrm{CO}_{2}$ (17.4 and 17.6 days, 
Table 5 .

Percentage of queens that started laying eggs after a certain time

\begin{tabular}{||c|c|c|c|c|c|c|c|c|c|c|c||}
\hline \hline Days & \multirow{2}{*}{$\mathrm{n}$} & \multicolumn{2}{|c|}{$<7$ days } & \multicolumn{2}{|c|}{$8-14$ days } & \multicolumn{2}{|c|}{$15-21$ days } & \multicolumn{2}{|c|}{$22-30$ days } & \multicolumn{2}{|c|}{$>30$ days } \\
\cline { 4 - 13 } $\begin{array}{c}\mathrm{CO}_{2} \\
\text { Concentrat-ion }\end{array}$ & & $\mathrm{n}$ & $\%$ & $\mathrm{n}$ & $\%$ & $\mathrm{n}$ & $\%$ & $\mathrm{n}$ & $\%$ & $\mathrm{n}$ & $\%$ \\
\hline $50 \%$ & 51 & 8 & $15.7 \mathrm{a}$ & 17 & $33.3 \mathrm{bc}$ & 10 & $19.6 \mathrm{a}$ & 10 & $19.6 \mathrm{ab}$ & 6 & $11.8 \mathrm{a}$ \\
\hline $75 \%$ & 46 & 0 & 0 & 10 & $21.7 \mathrm{abc}$ & 17 & $37.0 \mathrm{ab}$ & 8 & $17.4 \mathrm{ab}$ & 11 & $23.9 \mathrm{a}$ \\
\hline $80 \%$ & 47 & 2 & $4.2 \mathrm{a}$ & 5 & $10.7 \mathrm{a}$ & 15 & $31.9 \mathrm{ab}$ & 15 & $31.9 \mathrm{~b}$ & 10 & $21.3 \mathrm{a}$ \\
\hline $90 \%$ & 49 & 6 & $12.2 \mathrm{a}$ & 10 & $20.5 \mathrm{ab}$ & 21 & $42.9 \mathrm{~b}$ & 6 & $12.2 \mathrm{a}$ & 6 & $12.2 \mathrm{a}$ \\
\hline $100 \%$ & 50 & 0 & 0 & 26 & $52 \mathrm{c}$ & 9 & $18 \mathrm{a}$ & 9 & $18 \mathrm{ab}$ & 6 & $12 \mathrm{a}$ \\
\hline Total & 243 & 16 & 6.8 & 68 & 28 & 72 & 29.5 & 48 & 19.7 & 39 & 16 \\
\hline \hline
\end{tabular}

a, b, c - different letters indicate significant differences

(difference tests between two proportions) $\mathrm{p} \leq 0.05$.

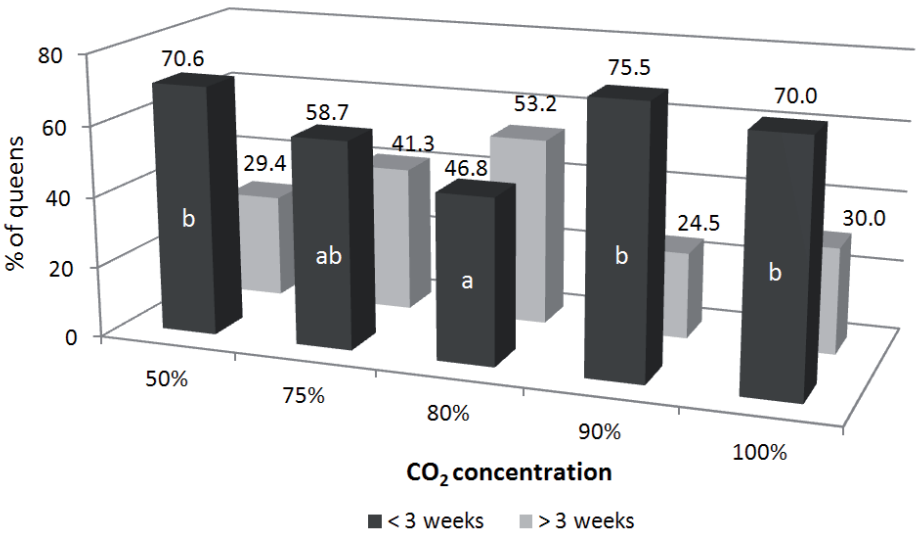

Fig. 2. Percentage of queens that started laying eggs within the first 3 weeks and later $a, b$ - significant differences (difference tests between two proportions) at $p \leq 0.05$.

respectively). The queens treated with $80 \% \mathrm{CO}_{2}$ began laying eggs significantly later (on average, after about 24.3 days). It was also found that the concentration of $\mathrm{CO}_{2}$ gas used during the insemination process significantly influences the initiation of oviposition by queens (Tab. 4).

The whole period of time from insemination to oviposition in all of the studied queens was divided into one-week periods. The division showed that within the first week from insemination, oviposition was started by $6.8 \%$ of queens, and among them only ones narcotized with 50,80 and $90 \% \mathrm{CO}_{2}(15.7 \%, 4.2 \%$ and $12.2 \%$, respectively) (Tab. 5). Within the second week after insemination, oviposition started in the next $28 \%$ of queens. It was noted that in this period, oviposition began in more than half $(52 \%)$ of queens narcotized with $100 \% \mathrm{CO}_{2}$. However, within the first 2 weeks after insemination almost half of the queens $(49 \%)$ treated with the lowest $\mathrm{CO}_{2}$ concentration, started laying eggs.

Participation of queens that started, and those that did not start laying eggs after 3-week period from insemination showed that oviposition began in: more than $70 \%$ of queens narcotized with $90 \%$ and $100 \% \mathrm{CO}_{2}$, more than half of queens narcotized with $50 \%$ and $75 \% \mathrm{CO}_{2}$, and only $46.8 \%$ of queens narcotized with $80 \% \mathrm{CO}_{2}$ (Fig. 2). 


\section{DISCUSSION}

The obtained results show that various concentration of carbon dioxide used for queen narcosis during instrumental insemination influences the immobilization moment and the regaining of consciousness as well as the length of unconsciousness. With the increase of $\mathrm{CO}_{2}$ concentration, the queens lost consciousness more quickly, which means they were immobilized sooner. The $\mathrm{CO}_{2}$ concentration also accelerates the introduction of the semen into the oviducts. Queens narcotized with carbon dioxide at lower concentrations (50 and $75 \%$ ) were able to move their bodies while under anesthesia (the time of $\mathrm{CO}_{2}$ exposure). This required the utmost attention from the inseminator when putting the needle into the sting chamber. It also increased the time of insemination. Similar observations were reported by Konopacka (1987, 1991). In her studies, queens treated with a short exposure of pure carbon dioxide were still able to move their abdomens, but lived longer than queens who had received two 10 minute $\mathrm{CO}_{2}$ gas treatments.

In our studies, the various concentrations of $\mathrm{CO}_{2}$ gas used during the insemination of bee queens did not have an influence the number of lost queens or the number of queens that did not start laying eggs. The rate of dead queens and non-egg laying queens reached, on average, $12 \%$. Similar results were obtained by Woyke and Ruttner (1976), Kühnert et al. (1989) and Otten et al. (1998). These authors used pure $\mathrm{CO}_{2}$ gas to anesthetize queens during insemination. In our research, slightly less than $7 \%$ of the queens treated with $100 \% \mathrm{CO}_{2}$ were lost.

In the present study, the time of carbon dioxide exposure (from the start of narcosis to the completed insemination), regardless of the $\mathrm{CO}_{2}$ concentration did not exceed $2 \mathrm{~min}$. The percent of queens that started oviposition was from 84.2 to $90.7 \%$. Other authors reached similar results (from 76.8 to $85 \%$ ), but only when using pure $\mathrm{CO}_{2}$ gas (Mackensen, 1947; Woyke and Ruttner, 1976; Ebadi and
Gary, 1980; Kaftanoglu and Peng, 1982; Konopacka, 1989). The above authors recommended using a double $\mathrm{CO}_{2}$ narcosis, before and during instrumental insemination or during and after insemination, for 3 or 10 minutes each. According to Janoušek (1987), 1-minute anesthesia is not dangerous for the queens.

In previous research, a relationship was found between oviposition and the carbon dioxide used for queen anesthesia. In our study, $15.7 \%$ of queens treated with $50 \% \mathrm{CO}_{2}$, and $12.2 \%$ of queens treated with $90 \% \mathrm{CO}_{2}$ started oviposition within the first week after insemination. By the end of the second week, $52 \%$ of queens treated for $30 \mathrm{~s}$. with pure $\mathrm{CO}_{2}$ had started laying eggs. Konopacka (1989) stated that in queens narcotized once with pure carbon dioxide for $1 \mathrm{~min}$, or two times for $0.5 \mathrm{~min}$ each, started oviposition, on average, 30 days (from 3 to 50 days) after insemination. According to Gerula et al. (2011), queens given one short treatment of $\mathrm{CO}_{2}$ oviposited 16-20 days after insemination. In the presented study, this period was much shorter and averaged 17 days (from 8 - 43 days). By the end of the second week after insemination, $49 \%$ of queens treated for $90 \mathrm{~s}$ with $50 \% \mathrm{CO}_{2}$ had begun to lay eggs.

Otto et al. (1998) suggest that the number of queens starting to lay eggs depends on the strength of the colonies they are introduced to. According to Otto et al., in weak bee colonies (with about 200 bees), less than $70 \%$ of instrumentally inseminated queens start oviposition, while in strong colonies (1200 bees), almost 95\% of queens start laying eggs.

Ebadi and Gary (1980) showed that queens anesthetized twice with $75 \% \mathrm{CO}_{2}$, laid eggs 3.7 days (3-4 days) after insemination. But when their queens were treated once with $75 \% \mathrm{CO}_{2}$, they laid eggs after 12 days (4 to 20 days). The results of our study do not confirm these reports. Queens that were anesthetized once with $75 \% \mathrm{CO}_{2}$ started oviposition, on average, 23 days after insemination (9-49 days). The highest number of queens 
that started oviposition in the shortest time from insemination were in a group of individuals treated once with $50 \% \mathrm{CO}_{2}$. They laid eggs, on average, 17.4 days (4-37 days) from insemination, while queens treated with $100 \% \mathrm{CO}_{2}$, on average, after 17.6 days (8-43 days) and queens treated with $90 \% \mathrm{CO}_{2}$ after 19.9 days (6-54 days). There were differences found in the oviposition between groups of queens treated with 50, 90 and $100 \% \mathrm{CO}_{2}$ concentrations and groups of queens treated with 75 and $80 \% \mathrm{CO}_{2}$.

\section{CONCLUSIONS}

1. The various carbon dioxide gas concentrations used during instrumental insemination of bee queens influence the time of immobilization (anesthetized) and waking up of queens.

2. With increasing $\mathrm{CO}_{2}$ concentration, the queens are immobilized faster.

3. The lower the concentration of $\mathrm{CO}_{2}$ gas, the longer the dosing time (from the start of anaesthesia to completion of insemination).

4. The various carbon dioxide gas concentrations used during instrumental insemination do not influence the rate of queens that start laying eggs.

5 . The various carbon dioxide gas concentrations used during instrumental insemination influences the time of oviposition.

6 . The queens which were anaesthetized with $50 \%, 100 \%$ and $90 \% \mathrm{CO}_{2}$ started oviposition in the shortest time.

\section{REFERENCES}

Alber M., Jordan R., Rutnetr F., Rutnetr H. (1955) - Von der Paarung der Honigbiene. Z. Bienenkunde, 3: 1-28.

Austin G. H. (1955) - Effects of carbon dioxide anesthesia on bee behavior and expectation of life. Bee World, 36: 45-47.

Bieńkowska M., Panasiuk B. (2006) Influence of the diameter of the inseminating needle tip on the results of bee queens' fertilization. J. Apic. Sci., (50)2: 137-145.
Bieńkowska M. Węgrzynowicz P., Panasiuk B., Gerula D., Loc K. (2008) - Influence of the age of honey bee queens and dose of semen on condition of instrumentally inseminated queens kept in cages with 25 worker bees in bee colonies. J. Apic. Sci., 52(2): 23-33.

Bieńkowska M., Loc K., Panasiuk B., Węgrzynowicz P., Gerula D. (2011) Effect of semen dose and application on the performance of instrumentally inseminated honeybee queens kept with 25 worker bees. J. Apic. Sci., 55(1): 99-109.

Czekońska K. (2009) - The effect of different concentration of carbon dioxide $\left(\mathrm{CO}_{2}\right)$ in mixture with air nitrogen upon the survival of the honey (Apis mellifera). J. Apic. Res., 48(1): 67-71.

Ebadi R., Gary N. E. (1980) - Factors effecting the survival, migration of spermatozoa and onset of oviposition in instrumentally inseminated queen honey bees, J. Apic. Res., 19: 196-204.

Ebadi R., Gary N. E., Lorenzen K. (1980) - Effects of carbon dioxide and low temperature narcosis on honey bees (Apis mellifera). Environ. Entomol., 9(1): 144-147.

Fischer F. (1990) - External influences on the filling of the spermatheca with sperm, Apidologie, 21: 359-360.

Gerula D., Bieńkowska M. (2008) Performance of artificially inseminated honeybee queens that have bodily injuries. J. Apic. Sci., (52)1: 13-20.

Gerula D., Bieńkowska M., Panasiuk B. (2011) - Instrumental insemination of honey bee queens Turing flight activity predisposition period 1. Onset of oviposition. J. Apic. Sci., (55)2: 53-66.

Gontarz A., Bieńkowska M., Loc K. (2005) - Effect of queen caging conditions on insemination results. J. Apic. Sci., (49)1: 5-15.

Harbo J. R. (1986a) - Oviposition rates of instrumentally inseminated and naturally mated queen honey bees fertilized by artificial insemination. Ann. Entomol. Soc., 79: 112-115. 
Harbo J. R. (1986b) - Propagation and instrumental insemination, in: Rinderer T.E. (Ed.), Bee Breeding and Genetics, Academic Press, Inc., pp. 361- 389.

Janoušek J. (1987) - Effect of carbon dioxide on initial oviposition of inseminated queens. Vedecke Prace Vyzkumneho Ustavu Vcelarskeho v Dole 9: 57-64.

Kaftanoglu O., Peng Y. S. (1982) - Effect of insemination on the initiation of oviposition in the queen honeybee. J.Apic.Res., 21: 3-6

Koeniger G. (1976) - Einfluss der Kopulation auf den Beginn der Eiablage bei der Bienenköningin (Apis mell. L.). Apidologie 7: 343-355.

Koeniger G. (1981) - In welchem Abschnitt des Paarungsverhaltens der Bienenkönigin findet die Induktion der Eiablage statt? Apidologie, 12(4): 329-343.

Koeniger G., Koeniger N., Fabritius M. (1979) - Some detailed observations of mating in the honeybee. Bee World, 60: 53-57.

Konopacka Z. (1987) - Biological quality of instrumentally inseminated queens, Proc. XXX1st International Apimondia Congress, Warsaw, pp. 163-167.

Konopacka Z. (1989) - Czynniki wpływające na wyniki sztucznego unasieniania matek pszczelich i ich jakość. [Factor influencing results of instrumental insemination of honey bee queens and their quality - in Polish]. Rozprawa habilitacyjna, ISK 1989.

Konopacka Z. (1991) - Wpływ narkozy $\mathrm{CO}_{2}$ i $\mathrm{N}_{2} \mathrm{O}$ na wyniki sztucznego unasieniania matek pszczelich. [Effect of $\mathrm{CO}_{2}$ and $\mathrm{N}_{2} \mathrm{O}$ an aesthetics on the results of instrumental insemination of queen honey bees - in Polish]. Pszczeln. Zesz. Nauk., 35: 3-18.

Kühnert M., Carrrick M. J., Allan L. F. (1989) - Use of homogenized drone semen in a bee breeding program in Western Australia, Apidologie, 20: 371-381.

Laidlaw H. H. (1954) - Beekeeping management for the bee breeder. Am. Bee J., (94)3: 92-95.

Laidlaw H. H. (1981) - Contemporary queen rearing. Dadant and Sons Hamilton, Illinois.
Mackensen O. (1947) - Effect of carbon dioxide on initial oviposition of artificially inseminated and virginqueen bees. J. Econ. Entomol., 40: 344-349.

Mackensen O. (1964) - Relation of semen volume to success in artificial insemination of queen honey bees. J. Econ. Entomol., (57)4: 581-583.

Otten C., Otto A., Renner R. (1998) - Artificial insemination: Methodological influences on the results. Apidologie, 29(5): 467-468.

Skowronek W. (1976) Mating behavior of queen honey bees after carbon dioxide anaesthesia. Pszczeln. Zesz. Nauk., 20: 99-115.

Skowronek W. (1982) - Effect of carbon dioxide anaesthesia on the function of Corpora allata in honeybee workers (Apis mellifera L.). Pszczeln. Zesz. Nauk., 26: 3-13.

Skowronek W., Jaycox E. R. (1974) - Effects of carbon dioxide on honey bee workers, Pszczeln. Zesz. Nauk., 18: 107-119.

Skowronek W., Jaycox E. R., Guynn G. (1973) - Effect of anaesthesia of honey bee queens on their attractiveness to workers. Pszczeln. Zesz. Nauk., 17: 11-15.

Wilde J., Sobiechowski K. (2002) - The effect of carbon dioxide treatment on mating of virgin honeybee queens. Pol. J. Natur. Sc., 12(3): 73-85.

Woyke J. (1960) - Naturalne i sztuczne unasienianie matek pszczelich. [Natural and instrumental insemination of honey bee queens - in Polish]. Pszczeln. Zesz. Nauk., 4: 183-275.

Woyke J. (1962) - Natural and artificial insemination of queen honey bees. Bee World, 43: 21-25.

Woyke J. (1966) - Factors that determine the number of spermatozoa in the spermatheca of naturally mated queens, Z. Bienenforsch., 8: 236-247.

Woyke J. (1979) - Effect of the access of worker honeybees to the queen on the results of instrumental insemination. J. Apic. Res., 19(2): 136-143. 
Woyke J. (1983) - Dynamics of entry of spermatozoa into the spermatheca of instrumentally inseminated queen bees. J. Apic. Res., 22(3): 150-154.

Woyke J., Jasiński Z. (1976) - The influence of age on the results of instrumental insemination of honeybee queens. Apidologie, 7(4): 301-306.

Woyke J., Jasiński Z. (1978) -Influence of age of drones on the results of instrumental insemination of honeybee queens. Apidologie, 9(3): 203-212.

Woyke J., Jasiński Z. (1979) - Number of worker bees necessary to attend instrumentally inseminated queens kept in an incubator. Apidologie, 10(20): 149-155.

Woyke J., Jasiński Z. (1980) - Wpływ liczby pszczół asystujących matce przed zabiegiem, na rezultaty sztucznego unasieniania. [Influence of the number of workers attending honeybee queens before manipulation on the results of instrumental insemination]. Pszczeln. Zesz. Nauk., 24: 3-8.

Woyke J., Jasiński Z. (1982a) - Influence of the number of attendant workers on the number of spermatozoa entering the spermatheca of instrumentally inseminated queens kept outdoors in mating nuclei. J. Apic. Res., 21(3): 129-133.
Woyke J., Jasiński Z. (1982b) - Comparison of the number of spermatozoa entering the spermatheca of instrumentally inseminated queens kept in nuclei and in normal honeybee colonies. Pszczeln. Zesz. Nauk., 27: 29-34.

Woyke J., Jasiński Z. (1990) - Effect of the number of attendant worker bees on the initiation of egg laying by instrumentally inseminated queens kept in small nuclei. J. Apic. Res., 29: 101-106.

Woyke J., Ruttner F. (1976) - Results, in: Ruttner F. (Ed.), The instrumental insemination of the queenbee, Apimondia, Bucharest, pp. 87-92.

Woyke J., Jasiński Z., Flisziekiewic C. (1995) - Further investigation on natural mating of instrumentally inseminated queen bees. J. Apic. Res., 34: 105- 106.

Woyke J., Fliszkiewicz C., Jasinski Z. (2001) - Prevention of natural mating of instrumentally inseminated queen honey bees by proper method on instrumental insemination. J. Apic. Res., 45: 101-114.

\title{
WPLYW RÓŻNYCH STĘŻEŃ DWUTLENKU WĘGLA STOSOWANEGO PODCZAS INSEMINACJI NA ROZPOCZYNANIE CZERWIENIA PRZEZ MATKI PSZCZELE
}

\author{
Bieńkowska M., Panasiuk B., Węgrzynowicz P., Gerula D. \\ S t r e s z c z e n i e
}

Badania prowadzono w latach 2004, 2005 i 2007 w Oddziale Pszczelnictwa w Puławach. Matki siostry rasy kraińskiej w wieku 7 dni unasieniano dawką $8 \mu \mathrm{l}$ nasienia. Matki usypiano jeden raz podczas sztucznego unasienienia. Do usypiania matek zastosowano mieszaninę dwutlenku węgla i głównych gazów powietrza w różnych proporcjach. We wszystkich latach badań wraz ze wzrostem koncentracji dwutlenku węgla użytego do narkozy matki zasypiały szybciej. Czas zasypiania matek wahał się od $6,1 \mathrm{~s}$ po zastosowaniu $100 \% \mathrm{CO}_{2}$, do $95,5 \mathrm{~s}$ po zastosowaniu $50 \% \mathrm{CO}_{2}$. We wszystkich latach badań istotnie najwięcej czasu (średnio $18 \mathrm{~s}$ ) poświęcono na wprowadzenie nasienia do dróg rodnych matek usypianych $\mathrm{CO}_{2}$ o najniższym, 50\%-owym stężeniu, a w niektórych latach (2004 i 2007 roku) również 75\%-owym stężeniu. Wraz ze wzrostem udziału procentowego dwutlenku węgla w narkozie zastosowanej w czasie inseminacji, matki spały istotnie dłużej. 
W badaniach wykazano, że stężenie dwutlenku węgla używanego do usypiania matek pszczelich nie miało wpływu na straty matek i liczbę matek rozpoczynających skłądanie jaj. Spośród 276 unasienionych matek, 243 (88\%) rozpoczęło czerwienie, a 33 (12\%) nie zaczęły czerwić lub padły przed zakończeniem doświadczenia. Najmniej takich matek stwierdzono w grupie matek usypianych $100 \% \mathrm{CO}_{2}\left(7,4 \%\right.$ ), a najwięcej w grupach usypianych $80 \%$ i $75 \% \mathrm{CO}_{2}$ (odpowiednio $14,5 \% \mathrm{i} 16,4 \%$ ). Matki pszczele rozpoczynały czerwienie po upływie 4 do 55 dni od dnia unasienienia. Wykazano, istotny związek między stężeniem dwutlenku węgla zastosowanego w czasie unasieniania matek pszczelich, a szybkością rozpoczynania przez nie składania jaj. Istotnie najszybciej, rozpoczynały czerwienie matki usypiane $50 \%, 100 \%$ i $90 \%$ dwwutlenkiem węgla - odpowiednio po 17,4, 17,6 i 19,9 dniach. Matki usypiane $80 \% \mathrm{CO}_{2}$ rozpoczynały składanie jaj istotnie później bo dopiero po upływie średnio około 24,3 dni. Ocena udziału matek czerwiących i nie czerwiących po 3-tygodniowym okresie oczekiwania od inseminacji wykazała że czerwienie rozpoczęło $46,8 \%$ matek usypianych $80 \%$ dwutlenkiem węgla ponad $70 \%$ matek usypianych dwutlenkiem węgla o stężeniu $50 \%, 90 \%$ i $100 \%$, ponad połowę matek usypianych $75 \%$ i zaledwie $46,8 \%$ matek usypianych $80 \% \mathrm{CO}_{2}$.

Słowa kluczowe: Apis mellifera, narkoza, dwutlenek węgla, azot, tlen, sztuczne unasienianie. 